Acta vet. scand. $1960,1,236-244$.

From the State Veterinary Medical Institute, Department of Pathology, Stockholm.

\title{
INTESTINAL STENOSIS IN CHICKENS - A SEQUELA TO INVAGINATION
}

By

K. A. Karlsson.

Intestinal invagination arises from local disturbances in peristalsis and is fatal unless treatment is given or spontaneous reduction occurs. An exception to this general rule can be found in those instances in which the serosal surfaces of the intussusceptum become fused, the intussusceptum becomes necrotic and is sloughed, and healing takes place. Cicatricial retraction at the site of invagination occurs readily but may not result in restitutio ad integrum. This outcome of invagination seems to be uncommon for it is scarcely mentioned in the standard textbooks and then mainly in connection with horses and cattle $(1,4,5)$. As far as chickens are concerned, healing of intestinal invagination appears to have been mentioned only once (4). Judging from the autopsy records of the State Veterinary Medical Institute, however, the lesion is not at all exceptional but represents a characteristic and not uncommon finding among the chicken autopsies. A description of the lesion based upon the cases encountered at the institute will be presented in this paper.

\section{OWN INVESTIGATIONS}

Among the approximately 50.000 poultry autopsies carried out between 1948 and 1959 , intestinal invagination with the intussusceptum remaining in situ has been recorded as the major finding in 47 instances and older lesions with sloughing of the intussusceptum and cicatricial stenosis was seen in 76 birds. All 123 lesions were encountered in the small intestine most often between the middle and caudal thirds. No characteristic clinical 
course could be adduced from the usually meagre information available.

The acute invaginations, generally single, were of the usual type, and occurred most of ten in conjunction with acute enteritis. Focal lesions in the intestinal wall such as tumors or spastic muscular hypertrophy have not been seen at the sites of invagination. In no instance was the Meckels' diverticulum, very common in poultry, involved in the invagination. Between these acute invaginations and older lesions arising from these could be observed a range of intermediate stages.

The lesions observed in healed intestinal invagination with cicatricial stenosis are quite similar from case to case. The nutritional state is poor, often to the point of inanition. On the external surface of the intestine can be seen a narrow annular depression (fig. 1). Corresponding to this external depression there is a circular elevation of the mucous membrane forming a stenosing collar. In cross-section (i.e. a section in the long axis of the intestine), the collar is triangular and consists of a whitishgrey, firm tissue covered by a partly necrotic mucous membrane. The stenosing collar is thickest in the region of the mesenteric attachment. Orally, the small intestine is fusiformly dilated over

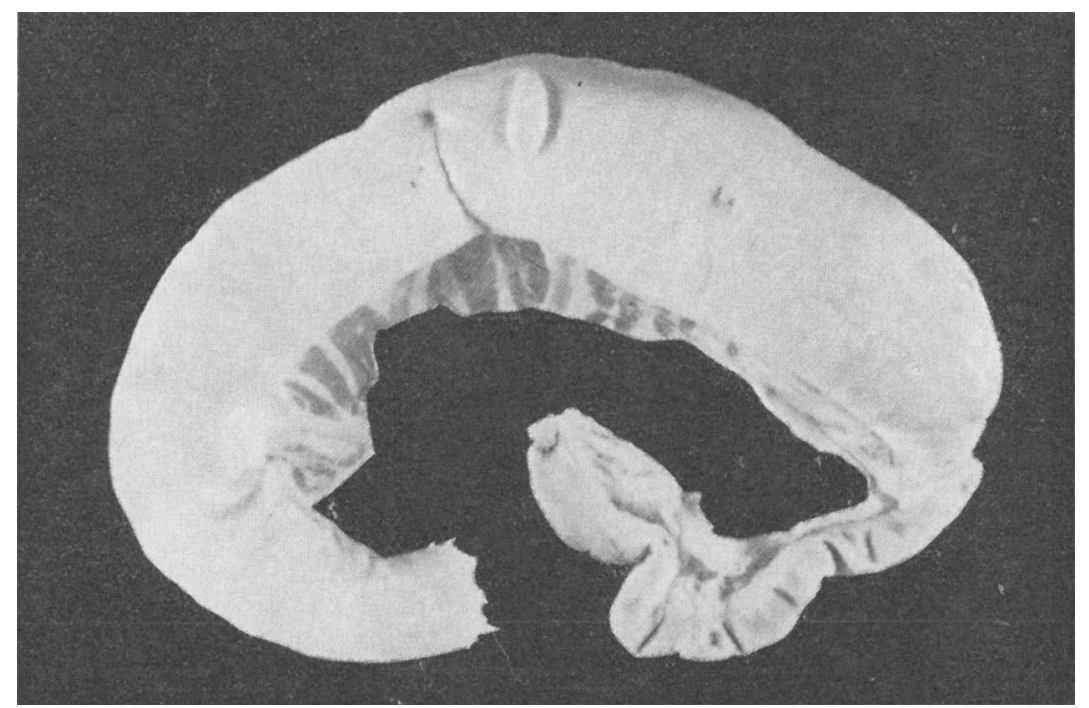

F i g. 1. Healed intestinal invagination with cicatricial stenosis (to the right). Dilatation of the oral intestinal segment and of Meckel's diverticulum (top). (0. 350/45). 
a distance of about $30 \mathrm{~cm}$ before gradually returning to normal dimensions and can have a diameter of 4 or $5 \mathrm{~cm}$ at its widest point. Within the dilated portion, the intestinal wall is moderately thickened, largely as a result of muscular hypertrophy. There is much poorly digested ingesta in the lumen and the contents have a loose but not watery consistency. A stercoral enteritis is often found. Caudally, the intestine is empty and contracted.

No traces of the intussusceptum as such can be found. In more recent cases - intermediate stages - the intussusceptum remains as a brownish-grey, dry necrotic mass, about $10 \mathrm{~cm}$ long. Various degrees of demarcation and sloughing have been observed (fig. 2).

Microscopically, (fig. 3) the peak of the stenosing collar is covered internally by a necrotic layer with little infiltration of round cells and without a distinct, cellular demarcation line between the necrotic and adjacent tissue. The slopes of the collar are covered by mucous membrane which shows signs of chronic fibrous enteritis with atrophy of the epithelium and a moderate round cell infiltration of the propria. Occasionally there is

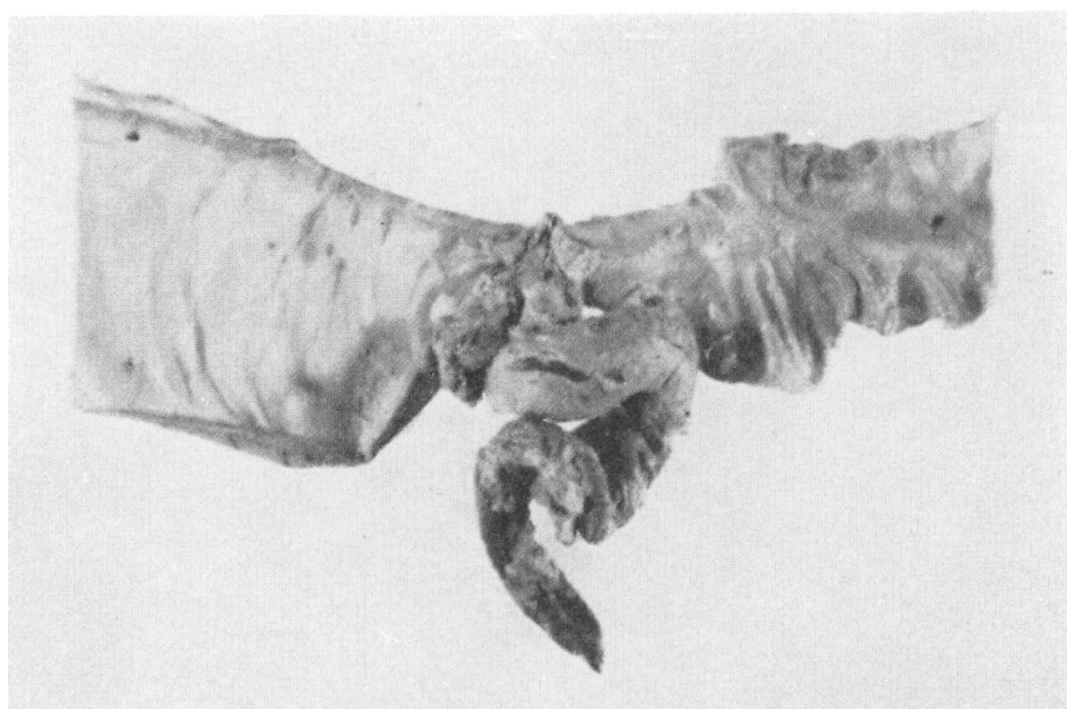

F i g. 2. Site of intestinal invagination opened showing the necrotic but persisting intussusceptum. Dilatation of the oral intestinal segment (to the left). (0.7766/49). 


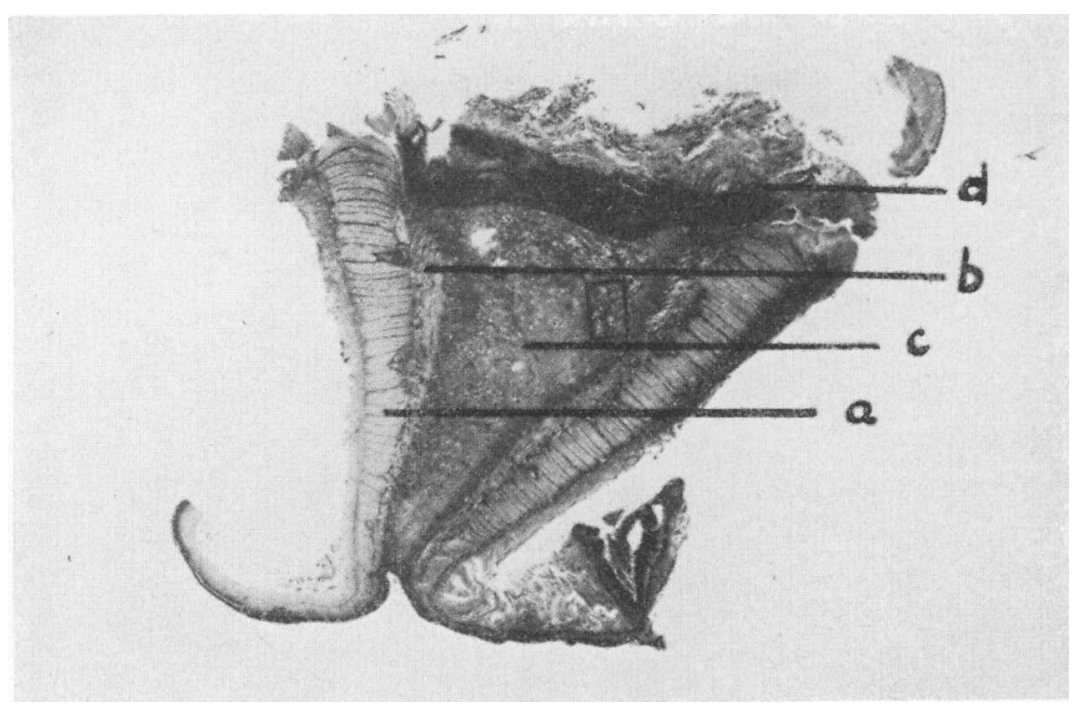

F i g. 3. Stenosing collar resulting from invagination. Note that the base of the collar is narrower than its peak; in most instances the converse is seen. This photograph clearly demonstrates the resemblance to an end-to-end surgical anastomosis between the oral and aboral intestinal segments. a - hypertrophied circular muscle layer, b - hypertrophied longitudinal muscle layer, c - granulation tissue containing islands of proliferating intestinal epithelium, $d$ - superficial necrosis. (O. 555/56, v. Gieson $4 \times$ ).

downgrowth of intestinal epithelium to the propria and even submucosa with the formation of alveoli (fig. 4).

The lamina muscularis mucosae and the lamina muscularis propria are hypertrophic on both the oral and the aboral sides of the collar. The degree of hypertrophy distinctly increases towards the peak of the collar and is invariably greatest in the circular muscular layer. The longitudinal muscle layer, on the other hand, is always interrupted at a point corresponding more or less to the peak of the collar and is here replaced by granulation tissue. Intestinal epithelium in alveolar or tubular arrangements can often be found in all muscle layers. It is usually quite easy to distinguish the various layers of the intestinal wall for the normal architecture is well preserved. Islands of granulation tissue, however, may occur between the various layers in the intestinal wall and even encroach to some extent upon them.

The major portion of the mass of the collar is situated under the longitudinal muscle layer. Fragments of serosa may be en- 


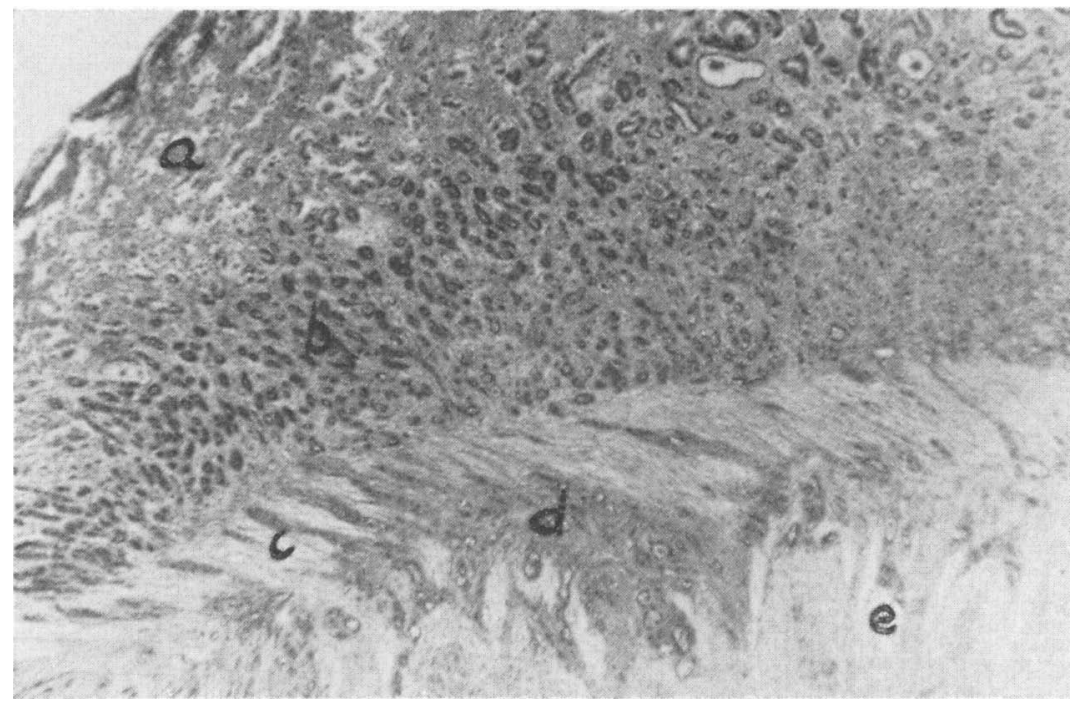

F i g. 4. Stenosing collar following intestinal invagination. a - superficial portion of the mucous membrane, $b$ - deeper portion of mucous membrane, c - deeper portion of mucous membrane with epithelial proliferation, $\mathrm{d}$ and $\mathrm{e}$ - submucosa and circular muscle layer, both containing islands of proliferating epithelium. (O. 7000/48, Hemalun$\operatorname{eosin} 44 \times$ ).

countered near the muscle layer but more peripherally, granulation tissue predominates. Proliferating intestinal epithelium may also be present (fig. 5). Islands of adipose tissue are interspersed in the granulation tissue about the mesenteric attachment.

The external surface of the intestine at the side of stenosis is covered by a normal or somewhat indurated serosa.

The morphology of the epithelial cells which can be encountered at all depths within the collar varies according to the degree of secretion to the lumina of the cell-groups. The cells are usually low cuboidal, occasionally cylindrical. The cell-groups may lie singly or in aggregations to give an adenomatous appearance. No signs of autonomous growth have been observed.

The size of the collar and consequently the degree of stenosis produced varies from case to case. In the larger collars there is much granulation tissue, the muscle layers in the oral and the aboral intestinal segments are widely separated, and the intestinal lumen is very narrow. In smaller collars, the ends of the longitudinal muscle layer may remain in close proximity and 


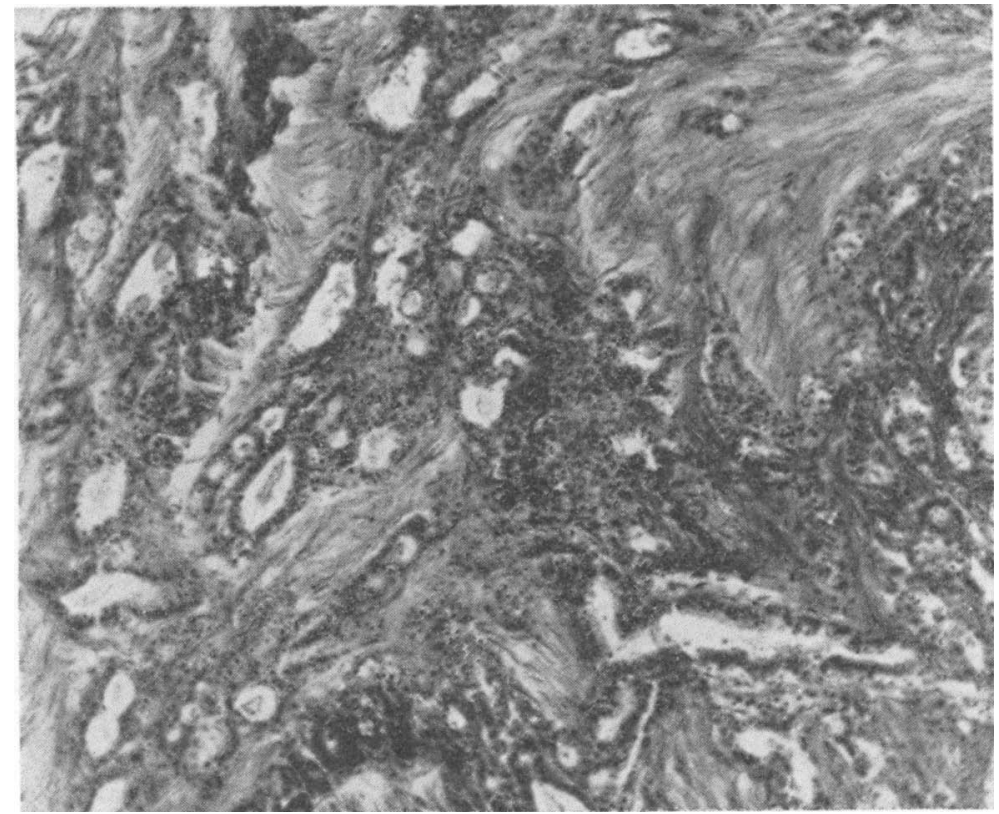

F i g. 5. Stenosing collar following invagination. Epithelial proliferation in granulation tissue. ( $0310 / 48$, v. Gieson $150 \times)$.

interruption of the other muscle layers may be difficult to demonstrate. The greater thickness of the collar along the mesenteric attachment and the inclusion of adipose tissue clearly indicate that a portion of the mesentery has been included in the invagination.

\section{DISCUSSION}

When one considers the over-all appearance of the lesions described here and especially the discontinuity in the longitudinal muscle layer, the resemblance to an end-to-end surgical anastomosis is striking. Such an appearance cannot reasonably be the result of anything but a healed invagination, and as has already been pointed out, a range of intermediate stages between acute invagination and collar-like stenosis have been seen.

The major portion of the collar is the result of a localised peritonitis developing from the adhesion between the opposed serosal surfaces at the site af invagination.

The extent and shape of the stenosing collar are undoubtedly determined by the amount of tissue at the base of the intussusceptum which remains after sloughing of the infarcted portion 
and by the inflammatory and reparatory processes which are induced. Cicatricial retraction and the morphological effects of a compensatory intestinal motility also seem to be involved. Cicatricial retraction is probably also responsible for the annular groove on the external surface of the intestine.

Muscular hypertrophy is encountered in both the oral and aboral portions of the stenosis. It appears likely that the hypertrophy in the oral portion is compensatory as is the muscular hypertrophy in the segment of small intestine oral to the invagination site. The muscular hypertrophy in the aboral portion of the collar has a more obscure origin. It is improbable that this hypertrophy was present prior to the occurrence of invagination. A local muscular hypertrophy, of course, could be the morphological expression for a spastic intestinal stenosis and invagination could occur as the result of attempts to force the obstruction by increased peristalsis. In such case, however, hypertrophy should have been situated aborally and not orally to the intussusceptum. Moreover, muscular hypertrophy was not seen in cases of acute invagination. It seems then, that the hypertrophy was the result rather than the cause of invagination. The stimulus to muscular hypertrophy which was effective on the oral side of the stenosis appears to have also been effective on the aboral side.

The ephithelial proliferation encountered in the mucous membrane, the muscle layers, and even in the granulation tissue comprising the major portion of the stenosing collar also appear to be part of the healing process for they are not found in acute invaginations. In spite of its often adenomatous appearance, the epithelial proliferation meets none of the criteria for authentic neoplasia. Much of this proliferation appears to originate from the mucous membrane covering the slopes of the stenosing collar. Some of the epithelial nests may represent islands enclosed in the granulation tissue during inflammation and organisation. The cause is most likely irritation during the course of events from acute invagination to cicatricial stenosis.

Histological sections from intestinal stenosis have quite naturally of ten been difficult to evaluate. The chicken intestine in any event rapidly undergoes autolysis after death and if stercoral enteritis is present, the process will be accelerated. When studies of this lesion were begun, the adenomatous epithelial proliferation was impressive and gave rise to the suspicion that this 
was the primary and significant alteration. As the number of specimens available for study gradually increased and there was a correspondingly greater opportunity for following events from acute invagination through intermediate stages, it become clear that cicatricial stenosis developed from acute invagination and that neither neoplasia nor any other proliferative process was the cause of this invagination. At the present time, cicatricial intestinal stenosis in poultry is encountered in a small but consistent number of the autopsies at the institute and is considered to be a lesion peculiar to this species.

The focal cause remains obscure, whereas the general prerequisite for an invagination, i. e. increased or disturbed peristalsis, is a common feature in poultry, mainly due to enteritis. Although the morphology of this chronic invagination has not revealed anything which is suggestive of a parasitic origin of the supposed enteritis, parasitism can be suspected. Parasitic enteritis is a comparatively common disease in poultry and it offers not only the potential risk of invagination, but also the possibility of localized lesions. Because the lesion, presumed to be the focal impetus must be situated at the anal part of the intussusceptum, it is always difficult to demonstrate its presence. If not sloughed, the intussusceptum as a rule becomes necrotic.

In the first part of this paper it was pointed out that the lesion had been mentioned only once previously (4). This is quite remarkable in view of the low but constant incidence in our autopsy material. There are, moreover, no known reports of annular epithelial intestinal tumors in chickens which could have been confused with the epithelial proliferation seen in the stenosis collars. A photograph of a specimen obtained by Baumann and published by Veenendaal (6) representing cicatricial stenosis in the intestine of a chicken shows many features in common with the cases of healed invagination described in this paper.

\section{REFERENCES}

1. Bruchmüller, A.: Lehrbuch der pathologischen Zootomie. Wien 1869.

2. Cohrs, P.: Lehrbuch der speziellen pathologischen Anatomie der Haustiere. Jena 1949.

3. Feldman, W. H. \& Olson, C. J.: In H. E. Biester and L. M. Schwarte: Diseases of Poultry, Ames, Iowa 1952.

4. Joest, E.: Spezielle pathologische Anatomie der Haustiere I. Berlin 1926. 
5. Kitt, Th.: Pathologische Anatomie der Haustiere II, Stuttgart 1911.

6. Veenendaal, H.: In T. v. Heelsbergen: Handbuch der Geflügelkrankheiten und der Geflügelzucht. Stuttgart 1929.

\section{SUMMARY}

The author gives an account of a well-defined, though not frequent, disease in chickens, characterized by a collar-like cicatricial stenosis in the small intestine which develops as a sequela of intestinal invagination after demarcation and sloughing of the intussusceptum. The disease has previously been described only once in the literature (4). In the present paper 123 cases of intestinal invagination are described, 76 of which were chronic with sloughing of the intussusceptum and cicatricial stenosis. The paper is based on a study of about 50.000 poultry autopsies.

\section{ZUSAMMENFASSUNG \\ Darmstenose bei Hühnern infolge von Invagination.}

Der Verfasser berichtet über eine charakteristische, wenngleichnicht allzu gewöhnliche Krankheit bei Hühnern, die sich als eine ringförmige Narbenstenose des Dünndarmes kennzeichnet. Die Stenose ist die Folge einer Invagination mit Demarkation und Abstossung des Intussusceptums. Nur ein einziger Fall dieser Krankheit ist vorher beschrieben worden (4). In der hier vorliegenden Arbeit berichtet der Verfasser über 123 Fälle von Darminvagination, von denen 76 chronisch waren mit Abstossung des Intussusceptums und Narbenstenose. Diese Arbeit stützt sich auf die Journale von zirka 50.000 Hühnerobduktionen.

\section{SAMMANFATTNING}

Tarmstenos hos höns som följd av invagination.

Författaren redogör för en karakteristisk, ehuru inte alltför vanlig sjukdom hos höns, kännetecknad av en ringformad ärrstenos av tunntarmen. Stenosen är en följd av invagination med demarkation och avstötning av intussusceptum. Endast ett fall av sjukdomen har tidigare beskrivits (4). I här föreliggande arbete redogör författaren för 123 fall av tarminvagination, av vilka 76 voro kroniska med avstötning av intussusceptum och ärrstenos. Arbetet bygger på en genomgång av c:a 50.000 hönsobduktioner.

(Received December 10. 1959). 